\title{
Think tanks and Foreign Policy in the United Kingdom
}

\section{Introduction, Influence and Causation}

Early in 2015, John de Boer, a senior policy advisor with the UNU Centre for Policy Research, published an article entitled What are Think Tanks Good For? For de Boer, the raison d'etre of a think tank is 'to serve as important catalysts for ideas and action' (de Boer, 2015).

Academic analysts of the increasingly dynamic and crowded world of policy advice have always faced the seemingly-intractable challenge of identifying - and evaluating - 'influence'. In an ideal scenario for the researcher, the role of policy-oriented institutions like think tanks would be direct and significant; for example, a decision-maker about to embark on a specific course of action would read a think tank publication, change his or her mind, and give the kind of public acknowledgement which is normally confined to Academy Award-winners. However, even evidence like this could not be taken at face value; as David Hume warned us, causation is never as simple as it seems on the surface.

De Boer's reference to 'catalysts' is useful to all students of think tanks, and is particularly relevant in the context of the present chapter. However, it does not remove the methodological difficulty since in science every catalyst is crucial; applied to policy influence, the word still implies a level of input without which decisions would have been different. Richard Higgott and Diane Stone (1994) have argued that evidence of think tank influence should not be confined to instances where decision makers seem to have changed their minds; such institutes can also perform a 'legitimising' role, lending credibility to the decisions and utterances of political actors. However, if taken too far, this approach could lead us to lower the bar for think tank influence to a point where all purveyors of policy advice in a specific area can (and often do) claim to have played some role, just by forming part of a relevant intellectual community. A think tank whose recommendations have been ignored could claim inclusion among the 'catalysts'; following John Milton's view that 'They also serve who only stand and wait', a policy institute which says nothing at all on the subject would also merit a mention.

While acutely conscious of these problems, in this chapter we take a broad view of 'influence' rather than focusing exclusively on cases which supply empirical evidence for the role of think tanks. Particularly in the fields of Foreign and Defence policy, contemporary British think tanks seek to foster rigorous dialogue and an exchange of ideas. The chapter is chiefly concerned with three prominent institutions - the Royal Institute for International Affairs (RIIA, or 'Chatham House'); the Royal United 
Services Institute (RUSI); and the International Institute for Strategic Studies (IISS). It begins with a brief discussion of the long-established British think tank tradition, locating these institutions within a framework of historical interpretation which applies to British think tanks in general. To varying degrees the three organisations owe their existence to the idea that the results of 'scientific' enquiry could affect the trajectory of foreign policy, if - and only if- people with expertise enjoy access to those making the policy. The chapter as includes a specific case study - namely, the role of think tanks in the run up to the Iraq War.

\section{The First Wave}

Although the term 'think tank' was unfamiliar to Britons until the 1970s, policy-oriented groups of varying degrees of institutional formality have a long history in the UK. The 'Philosophic Radicals' disciples of Jeremy Bentham's Utilitarian philosophy - exerted significant influence in several key policy fields in the nineteenth century, either as publicists or as MPs whose energies compensated for their lack of numbers. However, the Fabian Society (founded in 1884) bears a much closer resemblance to the think tanks of today and has a strong claim to be regarded as the first organisation of its kind; its original nine members were connected to an earlier group, 'The Fellowship of the New Life', but decided to form a separate Society because they wanted to engage more directly in policy-oriented work.

The Fabian Society was thus a self-conscious institution in a way that the Philosophic Radicals never were. Its members were, though, animated by a similar desire to influence policy decisions, and their main impulse came from a sense of ideological certainty. While the Philosophic Radicals were distinctively 'liberal', arguing for greater state activity where that seemed to coincide with the selfinterest of rational individuals, the Fabians took a more collectivist approach and saw themselves as 'socialists'; indeed, the Society was active in the foundation of the Labour Party in 1900 (by which time it boasted nearly a thousand members: Denham and Garnett, 2004).

Thus the early exemplars of the British think tank tradition were characterised by loose organisational structures, and a desire to influence policy which arose from clear ideological imperatives. Their numerous and notable successes arose from the fact that, before 1918, the decision-making process in Britain tended to be dominated by individuals who had even less claim to 'expertise' in specific areas. Despite reform of the civil service in the late nineteenth century, the cult of the 'Gentleman Amateur' still prevailed in Whitehall; and the individuals chosen by a restricted electorate to serve at Westminster 
tended to owe their places to social status rather than intimate acquaintance with any subject of political relevance. Intellectually, most MPs (and many ministers) were mediocre at best; the exceptions, like Lord Salisbury (Foreign Secretary 1878-80, 1885-6, 1887-92 and 1895-1900; Prime Minister 1885-6, 1886-92, and 1895-1902) might make a show of independent decision-making, but were usually wise enough to consult people with proven knowledge of topical subjects. In the absence of any overwhelming crisis to shake British complacency in the late nineteenth century, superficially it might look as if the old aristocratic elite was firmly in charge; but serious political operators outside government, who were aware of the growing economic and strategic challenges from Germany and US, could feel more confident of gaining a hearing, whichever party happened to be in office.

\section{The 'Second Wave' of UK think tanks}

The First World War shattered the illusions which had bred complacency amongst the British public. The conflict transformed worrying trends for policymakers into critical dilemmas, demanding careful consideration and well-informed responses. In the years between the World Wars, a 'second wave' of think tanks emerged in Britain, distinguished from the first in two key respects. First, these bodies were far more 'professional' even than the Fabians, whose members had included serious researchers like Beatrice and Sidney Webb as well as the polemical playwright George Bernard Shaw. As its name suggested, Political and Economic Planning (PEP: founded in 1931) focussed on the need for more rational policy-making and much more extensive government intervention in industry. The National Institute of Economic and Social Research (NIESR: founded in 1938) sought to provide policy-makers with more accurate statistical data. Second, although these institutions can be seen as key elements of an emerging 'Keynesian' consensus on industrial and economic policy, even their detractors would have to concede that they were very different from their 'First Wave' predecessors, whose policy advice was pre-determined by ideological considerations. For the 'Second Wave' bodies founded between 1918 and 1939, policy recommendations always had a marked ideological bias (usually towards greater state intervention); but the advice had to be based on intensive research, rivalling (if not surpassing) the work conducted in the respective government departments.

From the perspective of the current chapter, it is instructive that PEP and the NIESR were both founded in the 1930s, when Britain's relative weakness (and thus the case for independent sources of advice) had 
become obvious to any well informed citizen with an interest in domestic policy-making. By contrast, in the field of foreign policy the lessons of the First World War were digested much more rapidly. At the Paris Peace Conference of 1919-20 British officials agreed with their American counterparts on the need for an institute of international affairs. There would be a single 'parent' institute, with American and British branches. However, this plan met opposition in both countries, resulting in the formation of separate institutions: the Council for Foreign Relations (CFR: 1921) in the US, and the Royal Institute of International Affairs (1920: also known as Chatham House, from its occupancy of the former residence of the British Prime Minister William Pitt, Earl of Chatham, in St James' Square, London). Although the twin institutions were thus separated at birth, the main financial backing for Chatham House came from US sources.

The thwarting of this proposed transatlantic think tank partnership was probably fortuitous; the two institutions established amicable relations, avoiding the kind of tensions which might have arisen if they had been forced together. True, Britain and the US shared an overriding foreign policy interest - they both wanted global (particularly European) stability, in which they could pursue their trading interests. But this was a case of key interests coinciding, rather than being the product of a uniform world view based on similar self-images. Britain was a colonial power, whose resources were already overstretched even before the increase in its responsibilities which resulted from the Peace Conference. The US, by contrast, wanted to avoid Britain's mistakes, and to exercise economic dominance without taking direct responsibility in any of the territories which it effectively controlled. It was not difficult to predict that, in time, Britain would become one of those territories which the US hoped to influence (if not dominate) by remote-control. In contrast to the British, who allegedly had become Imperialists through forgetfulness, the US would pretend that it had forgotten to acquire an Empire. The British were now counting the cost of isolationism; most US policy-makers (along with the bulk of public opinion) assumed that their own nation could profit from it. After the years of complacency, British ministers and civil servants needed outside advice because the country's decline was too obvious to conceal from rational observers: the US government needed input from think tanks to help the country adjust to the global great power status which suddenly had been thrust upon it.

Initially established as the 'British Institute of International Affairs', Chatham House was awarded a royal charter in 1926 - a remarkable testament to its perceived importance within the UK's policy-making system, which further boosted the prestige of what was now the Royal Institute of International Affairs. Its self-adopted mission was to 'encourage and facilitate the scientific study of international questions, 
and to publish or arrange for the publication of works with these objects' (quoted in Wallace, 1975, 103). The idea that 'international questions' were amenable to scientific study was arresting, since it implied that catastrophes like the First World War could be avoided if only the 'scientists' in question were allowed to influence the decisions of bungling non-specialists. The same mood inspired the establishment of a Department of International Politics at Aberystwyth University, Wales, in the year of the Paris Peace Conference. In the inter-war years think tanks broadly similar to Chatham House were founded in countries which were either self-governing Dominions or still Colonies within the British empire - in Canada (1928), Australia (1932), South Africa (1934), India (1936) and New Zealand (1938).

A 'scientific' impulse also lay behind the foundation of the Royal United Services Institute for Defence and Security Studies (RUSI), but in this case the impulse came much earlier; indeed, when Chatham House was founded RUSI (established in 1831) was approaching its centenary year. Initially founded as 'The Naval and Military Museum', in 1839 it became 'The United Service Institution' and received the 'Royal' seal of approval in 1860 (although the monarchy had been strongly supportive from the outset). However, even the elastic term 'think tank' would have to be stretched too far to accommodate RUSI until fairly recently. It was designed as a forum in which members of the armed forces could discuss developments in the 'science' of war. As such, like Chatham House, RUSI provided a model for similar bodies worldwide. Only after 1963, on the initiative of a group of officers who wrote to The Times on the subject, did RUSI begin to evolve into a more independent and professional organisation with a wider membership.

If RUSI arose from an appreciation of the role of science in warfare, the Institution for International Strategic Studies (IISS) was inspired by a fear that scientific developments were putting the human race in jeopardy. In 1957 the British Council of Churches held a conference to discuss the implications of developments in thermonuclear weaponry, which had become even more relevant to the British public due to Soviet threats of retaliatory action in the Suez crisis of 1956. Discussions among politicians, journalists and retired military officers as well as clergymen resulted to the establishment of an institute whose main purpose should be 'the collection and dissemination of information about nuclear weapons and their implications for international relations' (Howard, 2008, 8). The decision to establish a think tank, committed to academic research in this sensitive area rather than political campaigning, coincided almost exactly with the formation of a highly-political pressure group, the Campaign for Nuclear Disarmament (CND), which was created at a public meeting in February 1958. 


\section{The Question of Influence}

As mentioned in the Introduction to this volume, even in an age of instant electronic communication geographical proximity to key decision-makers is very useful for think tanks. The IISS, Chatham House and RUSI are all based in central London, within walking distance of Westminster and Whitehall. True, if they want to visit IISS MPs, ministers and civil servants might be tempted to hail a taxi; but more energetic policy networkers would enjoy the stroll along the Thames embankment to Arundel Street, the location of the IISS. Chatham House is an even more agreeable destination, since St James' Square is adjacent to London's most prestigious clubs as well as being close to Whitehall and Westminster. British Foreign Secretaries have a private residence in nearby Carlton Gardens; until the Second World War the German Embassy was sited in Carlton House Terrace. But in terms of deceptively-spacious real estate with built-in potential for policy influence, even Chatham House is gazumped by RUSI. The Institute's website informs the first-time visitor that it can be found on Whitehall, 'between the Banqueting House and the Welsh Office, diagonally opposite Horseguards'. Coyly, it omits to mention that this puts it next door to the obtrusively large building which is home to the Ministry of Defence.

According to the University of Pennsylvania's authoritative rankings, these think tanks have made the most of their favourable locations. Among think tanks outside the US - of which the survey reckoned there were about 4,500 - RUSI is rated 25th. This is a very respectable showing for an organisation based in a middle-ranking state like Britain. However, RUSI was placed only third among the UK-based bodies, behind IISS $\left(4^{\text {th }}\right)$ and Chatham House (which came top). RUSI would have to console itself with a ranking of $10^{\text {th }}$ in the whole world among think tanks concerned with 'Defense and National Security' (although this still placed it behind IISS $\left(3^{\text {rd }}\right)$ and Chatham House $\left.\left(5^{\text {th }}\right)\right)$.

These rankings are based on a variety of factors, rather than attempting a crude assessment of direct policy influence. However, it is a reasonable presumption that the British think tanks working in the related areas of Foreign Policy, Security and Defence would not have been rated so highly by qualified observers if they were regarded as wholly lacking in such influence. The obvious question is whether this perceived influence can be supported by tangible evidence; and, as so often when think tanks are under discussion, it is difficult to supply a satisfactory answer.

Notoriously, in the crowded and competitive world of think tanks, many organisations have advertised themselves to prospective sponsors by highlighting instances (of varying plausibility) of policy ideas 
which have been taken up by policy-makers. In Britain, the Adam Smith Institute (founded in 1977) has been a prominent exemplar of this approach, although it also illustrated the potential hazards of selfadvertisement since one of its favourite policy ideas (a system of local taxation calculated on the basis of individual residents rather than their financial resources) resulted in a policy disaster which contributed to the forced resignation of Margaret Thatcher (Denham and Garnett, 1998, 151-73). This is emphatically not the usual style adopted by British think tanks in the area of foreign policy. If such bodies have gained a reputation for policy influence, it is not because they have boasted about it; at most, they tend to include in their publicity a few anecdotes which illustrate their longevity. One might say that they have exhibited a stereotypically British style of understatement, which has served them very well in reputational terms. Of course, those whose influence is limited, tend to be guilty of the opposite.

To an extent, however, this reticence has been enforced on Chatham House, RUSI and IISS by the prevailing culture of British decision-making in the fields of Foreign Policy and Defence. While an aggressive ideological 'Advocacy Tank' like the Adam Smith Institute enjoyed a licence to highlight (if not exaggerate) its influence because domestic policy makers have been hungry for outside advice (particularly since the 1980s), British Foreign Policy decisions have tended to be taken by a governmental elite which has rarely welcomed external advice. This attitude is reinforced by an unavoidable 'knowledge gap' between think tanks and the relevant ministries, which (usually) enjoy far greater resources in terms of information-gathering. A notable exception which reinforces this general rule was the wartime period of 1939-45, when the government's own channels of reliable information were impaired and it turned to Chatham House (temporarily based in Oxford) to help close its own 'knowledge gap'. Significantly, though, when 'normalcy' was restored in 1945 the think tank began to struggle; as the journalist Anthony Sampson noted 'it accumulated a lot of dead wood, and was even slower than the Foreign Office in realising the importance of Black Africa and the [EEC] (Sampson, 1965, 280).

Even on the rare occasions when policy-relevant knowledge held within think tanks rivals that of the respective government department, it still has to be translated into terms which are broadly compatible with official thinking. In a 1975 study published under the auspices of Chatham House, William Wallace alluded tactfully to 'the difficulty which even the most expert outsider experiences in discovering the terms of debate within Whitehall on his own field' (Wallace, 1975, 106). On this scenario, it is difficult for any foreign or defence policy think tank in Britain to influence policy in advance; at best, their 
analyses of decisions taken without their direct input might help to guide policy makers when they are faced with similar dilemmas, but even on those occasions their advice is unlikely to divert a government from its preferred course of action.

A second difficulty is that even in cases when influence seems to have been exercised, it is often unclear whether a policy outcome has been affected by the think tanks as institutions, or by eminent individuals who have been consulted because of reputations which owe little or nothing to their association with think tanks. This problem can be illustrated by two examples, one taken from the inter-war period and the other much more recent. The first is an unusual instance of a foreign policy think tank (in this case Chatham House) drawing attention to its past achievements. Its website mentions its special study group (formed in 1929) on the role of gold in international economics. The website states that the formation of this group 'anticipated Britain's decision to leave the Gold Standard two years later'. The obvious quibble here is that the decision to decouple the value of sterling from gold was involuntary because Britain's gold reserves were being depleted at an unsustainable rate - rather than arising from any specific policy advice. Leaving this aside, the study group included many renowned economists, notably John Maynard Keynes, who was well known as a critic of the gold standard long before he joined the Chatham House group (http://www.chathamhouse.org/about/history). The example thus proves that the RIIA was prepared to commission very serious studies of topical questions, and was capable of attracting participants of the highest calibre; but the question of influence remains unanswered (or, indeed in this instance, unanswerable). Did the connection with the RIIA lend weight to the group's deliberations, or did the participation of luminaries like Keynes make the RIIA's study group seem more important?

The more recent example is more pertinent, because it involves fewer ambiguities in terms of causation. Sir Lawrence Freedman, who had been a significant figure within both Chatham House and IISS for many years, undoubtedly played a leading role in the composition of Tony Blair's momentous speech delivered in Chicago in April 1999, which outlined the circumstances in which 'liberal' governments could (or should) intervene in civil conflicts (http://webarchive.nationalarchives.gov.uk/+/www.number10.gov.uk/Page1297 ). Whether or not Freedman's input merely added clarity and eloquence to thoughts which were already in Blair's mind, it would be churlish to argue that this should not count as direct influence, heralding not just a change in one particular decision but rather a shift in the framework within which numerous future decisions were taken. However, apart from his well-known work for think tanks Freedman had been Professor of War 
Studies at Kings College, London, since 1982. Was he asked to advise Blair on foreign policy issues because of his connection with think tanks, or because of the reputation he had established due to his professorial role (and his authorship of numerous academic books and articles)? The most plausible answer is that without his involvement in think tanks, Sir Lawrence might not have become so prominent as to attract the interest of the Blair Government, but that when he provided input to the Chicago speech he was doing so as a private individual.

Although positive examples of direct influence exercised by foreign policy think tanks is elusive, the early days of Blair's 'New Labour' government (1997-2007) offer a fascinating piece of negative evidence. Blair's first Foreign Secretary, Robin Cook, was antipathetic towards Chatham House, allegedly because it had treated his opinions with inadequate respect; The Times reported that he referred to the think tank as 'a graveyard of ex-diplomats'. Soon after his appointment to the Foreign Office, Cook (and Blair) supported the establishment of a new think tank, the Foreign Policy Centre, with a youthful Director, Mark Leonard. Unlike Chatham House, the new Centre was exploring ideas which senior New Labour found highly congenial, particularly in respect of an 'ethical dimension' to British decision-making (Little and Wickham-Jones, 2000, 13); although it is worth noting that in recent times, the centre identifies as independent, with co-presidents from the two major political parties (FPC, http://fpc.org.uk/about/ ). ${ }^{1}$

This example could be interpreted as back-handed testimony to the influence of foreign policy think tanks: senior figures within New Labour clearly thought that Chatham House played a significant role, since they took the trouble to promote a new body in the hope that it would perform similar functions in a more congenial fashion. The question remains, however, whether Cook and Blair wanted to contest Chatham House's perceived influence over policy, or whether their target was something less tangible the 'climate' of informed opinion.

\section{Informed opinion and foreign policy think tanks}

There is considerable support for the notion that, whatever their initial aspirations, British think tanks have long recognized that their most realistic goal in the areas of foreign policy and defence is to influence 'informed opinion', rather than hoping for direct decision-making input. Back in the 1960s William Snyder wrote that 'The direct influence of the IISS on British defence policy may be negligible; it

\footnotetext{
${ }^{1}$ In this spirit, the Foreign Policy Centre draws upon the work of academics, soliciting a select number to be research associates affiliated to the centre.
} 
has however, made an important contribution to the activities of the articulate public' (Snyder, 1964, 76). More recently, Robert Self has argued that the think tanks 'play a part in shaping the intellectual environment in which policy is made' (Self, 2010, 258).

Think tanks can contribute to 'shaping the intellectual environment' in two ways. Thanks to the convenient geographical locations of RUSI, Chatham House and the IISS, they provide 'neutral ground' for invited speakers who can attract audiences which might include policy-makers as well as journalists and prominent academics. Such events, and the ensuing discussions, can lead to specific policy decisions - in which case the think tanks, at least, will have acted as convenient facilitators for decisions which may or may not have been made in any case. Beyond this, conversations at such meetings can inform articles in journals and newspapers, thus contributing to general public discussion.

In addition, the think tanks themselves publish books and journals which enjoy relatively wide circulation among the 'informed' public. Chatham House's annual Survey of International Affairs, under the inspirational guidance of the think tank's Director of Studies Arnold Toynbee, was an indispensible text for students of British foreign policy between the wars. Its peer-reviewed journal, International Affairs (established in 1922) publishes six issues every year. The IISS publishes the highly regarded Adelphi Papers on specific issues at regular intervals and its journal, Survival, is also well rated. RUSI is responsible for numerous publications, notably its Whitehall Papers and the RUSI Journal, which first appeared in 1857.

While such publications enjoy considerable academic credibility, they strive to make complex issues seem accessible for the general reader - in contrast to a great number of academic publications, which appear designed to exclude a wider audience. However, the think tanks are well aware that their publications will not be consulted beyond the relatively small number of people who interest themselves directly in such matters. Self-consciously, they aim to publish material which will be accessible to journalists; as such, they act as intermediaries between the foreign policy 'elite' and the general public. In recent years, many have sought to get their work into the public forum, with an essay from Chatham House's The World Today featuring in the Observer's 'Worldview' each month.

One can appreciate the success of think tanks in helping to shape the intellectual argument by examining government sponsorship of their various activities. Freedom of Information (FOI) requests lodged by the present authors revealed that the Ministry of Defence (MOD)'s payments to RUSI have 
risen from $£ 32,871$ in $2010 / 1$, to $£ 226,524$ in $2014 / 5$. $^{2}$ This funding emanates from across 30 departments within the MoD. In contrast, MoD spending on Chatham House was split across just 9 departments. ${ }^{3}$

Contrary to this, the Foreign and Commonwealth Office (FCO) is listed as a 'partner' of Chatham House and is a corporate member, the cost of which, in 2015 , was $f 13,500$. In response to our FOI request for information on FCO funding of Chatham House, the Knowledge Services Manager (responsible for responding to FOIs) noted that: 'As a corporate member the FCO commissions services from Chatham House to assist with various projects around the world that help boost the UK's prosperity and relationships with other countries. These activities are funded by FCO Departments through their devolved budget'. This remark, and the details of departmental funding, raises interesting questions about the relationship between government and Foreign Policy think tanks, especially since these organisations - aside from the value of their properties - are far less affluent than their American counterparts. In their returns to the Charity Commission for 2014-15, Chatham House declared an income of $£ 14.5$ million; RUSI declared $£ 5.5$ million; while the figure for IISS was $£ 16.1$ million.

Moreover, the neutral ground provided by think tanks can also serve as a means of communication with other governments, in preference to more official channels. Almost from its inception Chatham House provided an informal diplomatic service, assisting the British government in negotiations with the US over war debts and naval disarmament in the inter-war period. It worked closely with the Foreign Office in dealings with issues relating to the 'Pacific Rim', especially through the Institute of Pacific Relations (IPR) until that body was dissolved in 1960 (Parmar, 2004, 23). During the 1980s it played an important role in maintaining communications between the UK government and the Soviet Union - an initiative which bore fruit when Britain was quick to identify the chances of rapprochement offered by Mikhail Gorbachev (interview with Lord Wallace of Saltaire). Along with proximity, think tanks like Chatham House offer deniability; they are close enough to decision-makers to carry credibility as surrogates for serving government officials in contacts of a sensitive nature, while remaining sufficiently detached to

\footnotetext{
${ }^{2}$ Aside for 2012's spending which was greater than 2013, the pattern is consistent across the 5 years.

${ }^{3}$ In 2010/1 this figure wasf 790 , in $2011 / 2$ it was $f 16,329$, while in $2012 / 3$ there was no spending. In $2013 / 4$ spending totaled $£ 32,035$ while in $2014 / 5$ it dropped to $£ 1,675$.
} 
avoid causing political embarrassment should such contacts become public knowledge. Such avenues to influence, of course, are not readily available to think tanks working in other fields.

\section{Case study: think tanks and the Iraq War}

In the months before the 2003 invasion of Iraq, think tanks played a prominent role in facilitating debate, but also in creating and shaping perceptions. On $21^{\text {st }}$ February 2003, Jack Straw - then Foreign Secretary - spoke at Chatham House, making the case for military action. Straw prefaced his comments on Iraq by thanking Professor Bulmer-Thomas, the Director of Chatham House, and his team on behalf of the FCO for their efforts over the past 12 months. Straw continued:

It's hard to overstate the importance of our partnership with Chatham House. As we enter an uncertain new era in international affairs, it's all the more important that FCO staff are able to step back from the day to day vicissitudes of diplomacy and develop a strategic perspective on the environment in which they operate. Chatham house has performed this invaluable service for British diplomats for the past 80 years (http://www.theguardian.com/politics/2003/feb/21/foreignpolicy.iraq)

Straw's comments stress the importance of Chatham House in several ways. The Foreign Secretary went on to acknowledge the importance of allowing policy makers to meet with academics to discuss emerging issues.

The selection of Chatham House as the venue for the speech demonstrates the perceived importance of the RIIA. However, it was not the only venue chosen by Straw to outline the case for British action, as he delivered a similar speech at the IISS. Six months earlier, the Institute had published an 80 page dossier, exploring Iraq's military capabilities. The dossier drew upon the experience of UN weapons inspectors who had been in Iraq but, as The Guardian noted, the dossier has as much that can be used to make arguments against military action as it does to advocate it (Norton-Taylor, 2002 http://www.theguardian.com/world/2002/sep/10/iraq.politics ).

Dr John Chipman, Director General of IISS, echoed this view, stating that the dossier 'does not attempt to make a case, either way, as to whether Saddam Hussein's WMD arsenal is a casus belli per se'. However other interested parties disagreed. Actors in the media selected material from the IISS dossier and 'spun' the report in an attempt to exacerbate the WMD threat. The dossier itself was a considered 
piece of work, providing scope for interpretation. However, in the coming months the nuances in the document itself were overlooked as the British government exploited it as justification for going to war.

As Kim Sengupta noted in The Independent

The IISS dossier on Iraqi weapons of mass destruction, published on 9 September 2002.... was immediately seized on by Bush and Blair administrations as providing "proof" that Saddam was just months away from launching a chemical and biological, or even a nuclear attack. Large parts of the IISS document were subsequently recycled in the now notorious Downing Street dossier, published with a foreword by the Prime Minister, the following week

To some denizens of the think tank world, the IISS had found itself in a kind of utopia where one of its productions had not only exercised a profound influence on government strategy, but was the subject of intense media discussion. In reality, of course, the incident threatened to damage the IISS's reputation for impartial analysis. It came at a time when the IISS was seen to be superseding Chatham House as a source of policy advice and a venue for conferences, thanks to its intimate links with the US State Department and the Pentagon as well as the UK's Foreign Office (Dickie, 2004, 181). In reality, IISS was receptive to a wide range of views on the Iraq crisis. In 2002 its journal Survival published a piece which concluded with the very prescient advice that 'If America decides to go into Iraq, it had better do so with its eyes wide open' (Gordon, Indyk and O'Hanlon, 2002, 21). To illustrate the Byzantine complexity of think tank activity, the authors were attached to the Brookings Institution rather than IISS. In any event, their warning was ignored by the US, even if it was not entirely lost on the British.

\section{Conclusion}

If the story of the IISS and the Iraq dossier suggests that when think tanks sup with governments they should use long-handled cutlery, the fact remains that a close relationship is indispensible. For think tanks in this field, a desire for complete independence equates to total impotence. Economic think tanks (for example), can criticise government programmes with virtual impunity, so long as their arguments have a sound statistical basis. Thus, for example, the Institute for Fiscal Studies (IFS) has enhanced its reputation in the UK through its unflinching analysis of government proposals, particularly in the current 'age of austerity'. However, issues relating to war and peace evoke a quite different response; criticism of government decisions, however, well-founded, can lead to accusations that a think tank is 
'unpatriotic', threatening to deprive it of its audience among the wider public as well as decisionmakers.

Foreign Policy think tanks are sufficiently distinctive from other policy institutes to require different standards of appraisal on the question of institutional independence. But if the British institutions truly deserve lofty reputations, they can still negotiate these delicate relationships to the advantage of all parties; they will attract well-placed speakers and contributors to their publications, and act as venues for informed discussions, without compromising their intellectual integrity. Thus, the announcement in 2015 that the former Conservative Foreign Secretary Lord (William) Hague was to assume the chairmanship of RUSI in September was unlikely to endanger its reputation; while RUSI would benefit from association with a senior member of the ruling Conservative Party, Hague augmented his image as a statesman whose insights into global developments transcended mere party politics.

No-one who reads the numerous publications of the British Foreign Policy think tanks could dismiss them as elitist bodies who consciously address themselves to a closed world of decision-makers. In this respect, they are clearly committed to the transmission of knowledge in digestible form, either through their own organs or through media outlets, including radio and television as well as serious newspapers and magazines. If they have not succeeded in expanding the sphere of 'informed opinion' in matters of foreign policy, it has not been for want of trying, especially in recent years when they have made their publications freely available on the internet. Ultimately, the British Foreign Policy think tanks have been trying to gain traction with two unheeding audiences - policy makers who (usually) assume that they can do their work without help from non-governmental bodies, and a public which (usually) only recognises its need to be better-informed when government decisions have already been taken. Faced with these ingrained attitudes in the British context, it is not surprising that the think tanks have failed in relation to their original objectives; the wonder is that, in spite of everything, they keep on trying to fulfil them.

\section{Bibliography}

de Boer, J (2105) 'What are Think Tanks Good For?' United Nations University, http://cpr.unu.edu/whatare-think-tanks-good-for.html. 
Denham, A., and Garnett, M (1998), British think tanks and the climate of opinion, UCL Press.

Denham, A., and Garnett, M (2004), 'A hollowed-out tradition? British think tanks in the twenty-first century', in Stone, D and Denham A (eds), Think Tank Traditions: Policy research and the politics of ideas, Manchester University Press, 232-46.

Dickie, J., (2004), The New Mandarins: How British Foreign Policy Works, I. B Tauris.

Gordon, P., Indyk, M, and O'Hanlon, M (2002), 'Getting Serious about Iraq', Survival, 44, 9-22.

Higgott, R., and Stone, D. (1994), 'The limits of influence: foreign policy think tanks in Britain and the USA', Review of International Studies, 20, 15-34.

Howard, M. (2008), 'Present at the Creation', Survival, 50, 5-8.

Little, R., and Wickham-Jones, M (eds) (2000), Labour's Foreign Policy: A New Moral Crusade?, Manchester University Press.

Parmar, I. (2004), 'Institutes of International Affairs', in Stone, D., and Denham, A. (eds), Think Tank Traditions: Policy research and the politics of ideas, Manchester University Press, 19-33.

Norton-Taylor, R. (2002), 'The Iraqi threat: real or imagined?, The Guardian, 10 September.

Sampson, A. (1965), The Anatomy of Britain Today, Hodder and Stoughton.

Self, R., (2010), British Foreign \& Defence Policy since 1945, Palgrave Macmillan.

Sengupta, K., (2004), 'Occupation made war less safe, pro-war institute says', Independent, 26 May (http://www.independent.co.uk/news/world/middle-east/occupation-made-world-less-safe-prowar-institutesays-6169169.html).

Snyder, W. (1964), The Politics of British Defence Policy 1945-1962, Ernest Benn.

Wallace, W. (1975), The Foreign Policy Process in Britain, Royal Institute of International Affairs. 